\title{
ASSESSMENT METHODS USED IN DETERMINING THE BIOREMEDIATION POTENTIAL OF MICRO ALGAEIN TREATMENT OF INDUSTRIAL EFFLUENTS: A REVIEW
}

\author{
1S. V. Hajare and ${ }^{2}$ A.A. Kulkarni \\ *1Mahatma Phule Mahavidyalaya Pimpri, Pune-17. \\ 2BPHE Society's Ahmadnagar College, Ahmadnagar \\ Email: swapanahajare@gmail.com
}

\begin{abstract}
:
Bioremediation is a process used to treat contaminated media, including water, soil and subsurface material by altering environmental conditions to stimulate growth of microorganisms and degrade the target pollutants. With the growing industrialization and urbanization, organic pollutants are accumulated in the aquatic ecosystem and fresh water bodies through the industrial discharges, untreated domestic effluents, agricultural runoff which includes pesticides, herbicides and fertilizers. These are responsible for adding excess nutrient load and change the quality of water and also causes negative effects on aquatic ecosystem as well as organisms which are depend on it. Similarly heavy metals, radio nucleotides which are released into the land and water reservoirs through nuclear power plants in accidental cases and their long term exposure to humans is detrimental as they are carcinogenic. There are several conventional methods such as coagulation and filtration, chemical precipitation, carbon adsorption, ion exchange, evaporations and membrane processes to minimize these contaminants but they might be including improper handling, disposal problem of sludge and high capital cost. Use of algae to minimize the contaminants or to detoxify the polluted water bodies is a more promising, ecofriendly and cost-effective method also known as phycoremediation. In this current review we will highlight on various methods used to assess the bioremediation potential of some micro algae in treatment of industrial effluents.
\end{abstract}

Key words :- Industrial effluents, heavy metals, microalgae, bioremediation assessment methods.

\section{INTRODUCTION:}

Now a days increasing population, urbanization and industrialization results in to environmental pollution which become a serious problem to the humans, animals and also terrestrial and aquatic life. Major natural resources like soil, water and air are contaminated by various anthropogenic activities. These activities include waste discharge from industrial processing, such as petroleum refinery, mineral mining, and chemical manufacturing, and agricultural activities. Most of these waste materials are released into the water reservoirs like sea, river, lake, pond, etc. These wastes mostly contain organic material in the form of $\mathrm{N}$ and $\mathrm{P}$ which add nutrient load into water reservoir leads to eutrophication, uncontrolled spread of certain aquatic macrophytes and oxygen depletion. Eutrophication increases the biological oxygen demand and alters the $\mathrm{pH}$ of water and makes it unhealthy for aquatic life (Amin et al., 2008). Many industries like electroplating, tanning, paper, textile etc. are main reasons of discharging effluents causing heavy metal pollution. Heavy metal pollutants like Mercury $(\mathrm{Hg})$, Cadmium $(\mathrm{Cd})$, Chromium $(\mathrm{Cr})$, Lead $(\mathrm{Pb})$, Nickel $(\mathrm{Ni})$ and Zinc $(\mathrm{Zn})$ causes poisoning which can occur through drinking water or intake via food chain. These heavy metals accumulate in the food chain of aquatic and terrestrial ecosystem posing health hazards (S.S. Ahluwalia and D. Goyal,2007). Similarly, soil contamination and remediation of 
polluted sites have become a worldwide priority with the increasing environmental concerns (Bundschuh et al., 2012; DEA, 2001; Luo et al., 2009; SSR, 2010). Various physical and chemical methods are available for removal of pollutants from contaminated water and soil like coagulation and filtration, sedimentation, chemical precipitation, carbon adsorption, ion exchange, evaporations and membrane processes, flocculation, etc. (Wang J. and Chen C. 2009). Most of these processes produce secondary and tertiary pollutants which again require some more steps for removal of contaminants. These physicochemical methods have some drawbacks as it requires high cost, disposal problem of sludge and not ecofriendly. The use of biological materials, including micro-organisms, to remove and detoxify industrial waste waters has gained popularity over the years due to increased performance, availability and low cost of raw materials (S.S. Ahluwalia, D. Goyal 2007 and S. Bunluesin et.al. 2007) microorganisms including bacteria (M.I. Ansari, A. Malik 2007). Algae (N. Mallick 2003) and fungi and yeasts (A.Y. Dursun 2003) can efficiently accumulate heavy metal from their external environment (K.N. Ghimire et.al.2003.andM. Ziagova 2007). The ability of algae to take up nutrients and remove pollutants from wastewater efficiently (Hoffman 1998; Sturm and Lamer 2011), and the possibility of producing high-energy biomass from them (Rawat et al. 2011; Park et al. 2011) attracted the interest of many scientists around the world in recent some years. Developing of biological based treatment system considered as economically cheaper and more environment friendly (Valderrama, 2002). Algae is an aquatic, autotrophic organism found in fresh as well as marine water and requires nutrients like nitrogen, carbon phosphorous, etc. from water along with sunlight for its survival (Johnson M 2016). It has ability to absorb these contaminants like organic wastes, heavy metals, pesticides, etc. as a part of its nutrition (Oswald, 2012) and metabolize it into less harmful compounds (Mitra, N 2012). Most of the algal strains have ability to survive in high concentration of heavy metals and other toxic contaminants (Howe G. and Merchant S., 1992.Harneet et.al. 2019). The process where the pollutants enter into algal cell cytoplasm and degraded by enzymes to convert them into nutrients is known as chemisorption (Dwivedi, S.,2012). They have ability to grow autotrophically as well as heterotrophically (Chekroun K. and Baghour M. 2013). Microalgae are phototrophic unicellular organisms found individually or in groups that consume carbon dioxide, nitrogen and phosphorus, and release oxygen. Algae have an affinity for polyvalent metals and are very effective in removing heavy metals, nitrates and phosphates present in wastewater (Saikumar C 2014). Therefore, use of algae for bioremediation of industrial wastewater offers potential advantages over other techniques in use Microalgae has an ability to convert inorganic nitrogen only in the forms of nitrite, nitrate and ammonium to organic nitrogen through a process called assimilation (Cai S 2013). Phosphorus is found in lipids, proteins and nucleic acids. It plays a crucial role in cell growth and metabolism of algae. During algae metabolism, phosphorus mainly in the forms of $\mathrm{H} 2 \mathrm{PO} 4-$ and HPO4- is incorporated into organic compounds through a process called phosphorylation (Saikumar C2014). Microalgae also require metals for their biological functions. Commonly used species for treating wastewater and removing heavy metals are Chlorella vulgaris, Scenedesmus dimorphous, Neochloriso leoabundans, Nannochloroposis, Spirulina, Botrycoccus braunii, Dunaliella salina etc (Rawat I. 2011). The present review is related with the role of micro algae in bioremediation and the different assessment methods used in analysis of 
decontamination after the treatment of various industrial effluents including waste water.

\section{Methods of bioremediation}

There are mainly two types of bioremediation Insitu bioremediation in which the microbial activity is enhanced by addition of more microorganism and nutrients at source of contamination. It is further classified into two approaches of which first approach is Intrinsic bioremediation or natural attenuation that deals with stimulation of indigenous or naturally occurring microbial populations by feeding them nutrients and oxygen to increase their metabolic activity and second approach is Engineered in situ bioremediation involves the introduction of certain microorganisms to the site of contamination Engineered in situ bio remediation accelerates the degradation process by enhancing the physico-chemical conditions to encourage the growth of microorganisms(bioventing, biosparging and phytoremediation) . In situ bioremediation techniques have been successfully used to treat chlorinated solvents, dyes, heavy metals, and hydrocarbons polluted sites (Folch et al. 2013; Kim et al. 2014; Fras cari et al. 2015; Roy et al. 2015).Ex-situ bioremediation which includes the removal of wastewater away from the contaminated site and move to treatment site such as biopile, windrows, bioreactor and land forming (SasikumarC.S. and Papinazath T.2003, Philp and Atlas 2005,Murali, O. and S.K. Mehar, 2014, ,)

\section{Physico-chemical assessment methods}

These are the commonly used qualitative analysis methods to check the quality of contaminated water which helps to assess and compare quality of pretreated and treated water in both In-situ and Ex-situ bioremediation method. It includes colour, pH, acidity, alkalinity, hardness, BOD, COD and DO. APHA (1998) demonstrate the colour and $\mathrm{pH}$ test. The colour intensity of water will be observed from naked eyes and $\mathrm{pH}$ - the $\mathrm{pH}$ will be measured by the digital $\mathrm{pH}$ meter. Calibration of the $\mathrm{pH}$ meter will be accomplished by $\mathrm{pH}$ electrode submerged in a $\mathrm{pH} 7$ buffer solution. Yati Prabha (2012) mentioned some following Physico-chemical methods use in determining the Potential of Algae in Bioremediation of Waste Water as

Acidity is measured by titration of water sample by using $\mathrm{NaOH}$ and indicator Methyl Orange or Phelophthalein and calculated by using formula Acidity $(\mathrm{mg} / 1)$ as $\mathrm{CaCO} 3=$

$\underline{\mathrm{NaOH} \text { total titration vol. in } \mathrm{ml} \times 0.05 \mathrm{~N} \times 1000 \times 50}$ $\mathrm{ml}$ of sample taken

Alkalinity is also measured by titrating water sample against $0.1 \mathrm{~N} \mathrm{HCl}$ and indicator Methyl Orange Phelophthalein and calculated by using formula

Alkalinity $=\underline{\text { Total } \mathrm{HCl} \times 0.1 \mathrm{~N} \mathrm{HCl} \times 1000 \times 50}$ $\mathrm{ml}$ of the sample

Hardness of water sample will be measured by EDTA Titrimetric Method (Ambast, 1990). The reagent used in this methos are Buffer solution $(\mathrm{pH}=10)$, Erichrome Black $\mathrm{T}$ indicator (EBT)., EDTA Titrant $(0.01 \mathrm{M})$ and it is calculated as Hardness $(\mathrm{mg} / 1)=\underline{\text { EDTA used }(\mathrm{ml}) \times 1000}$ $\mathrm{ml}$ of sample.

TSS- For the measurement of TSS a known volume of sample will be titrated through oven dried pre-weighted filter paper and the residue containing filter paper was oven dried at $100^{\circ} \mathrm{C}$ and again weighted.TSS of the sample will be calculated by following formula-

TSS $(\mathrm{mg} / 1)=$ initial weight of filter paper- final weight of filter paper

TDS -For measuring TDS water sample will be taken and then filtered it to remove suspended particles. $250 \mathrm{ml}$ of clear filtrate will be evaporated in an oven at $100^{\circ} \mathrm{C}$ in porcelain disc Measurement will be observed by formula $\operatorname{TDS}(\mathrm{mg} / 1)=\underline{\mathrm{W} 2-\mathrm{W} 1 \times 1000}$ 
Where, W1 = weight of empty disc W2= weight of oven dried disc $\mathrm{V}=$ volume of sample taken $(\mathrm{ml})$

Total Solids (TS) Total solids include both suspended and dissolved solids. It is calculated by using the formula TS $(\mathrm{mg} / 1)=$ TSS+TDS

Dissolved Oxygen (DO)is determined by titration method in which reagents like Conc. H2SO4 Manganous sulphate solution, Alkali iodide azide solution, Starch solution, Sodiumthio sulphate solution $(0.1 \mathrm{~N})$ are used. calculated by following formula

$$
\mathrm{DO}(\mathrm{mg} / \mathrm{l})=\frac{\left(8^{*} \times 1000 \times \mathrm{N}\right) \times \mathrm{V}}{\mathrm{V}}
$$

Where, V= volume of the sample taken $(\mathrm{ml}) \mathrm{v}=$ volume of the titrant used $\mathrm{N}=$ normality of the titrant $8^{*}=$ it is the constant since $1.0 \mathrm{ml}$ of 0.025 sodium thio sulphate solution is equivalent to $0.2 \mathrm{mg}$ of oxygen.

Biological Oxygen Demand (BOD) is determined by using reagents Phosphate buffer ( $\mathrm{pH}$ 7.2) MgSO4 solution $\mathrm{CaCl} 2$ solution $\mathrm{FeCl} 3$ solution Sodium Sulphite Solution $(0.025 N)$ and calculated by the following formula

$\mathrm{BOD}(\mathrm{mg} / 1)=[\{(\mathrm{DO} 2-\mathrm{DO} 1) \times 100\}(\mathrm{DO} 2-\mathrm{DO} 0)\}]$

Chemical Oxygen Demand(COD) is carried by using reagent $0.1 \mathrm{M}$ Potassium dichromate solution Sodium thio sulphate $(0.1 \mathrm{M})$ Sulphuric acid (2M) $10 \%$ of Potassium iodide solution $1 \%$ Starch solution and will be calculated by applying the formula

COD of the sample $(\mathrm{mg} / 1)=\underline{8 \times \mathrm{C} \times(\mathrm{B}-\mathrm{A})}$

$\mathrm{S}$

Where, $\mathrm{C}=$ concentration of the titrant $(\mathrm{mM} / 1) \mathrm{A}=$ Volume of the titrant used for blank (ml)

$\mathrm{B}=$ Volume of the titrant used for sample $(\mathrm{ml}) \mathrm{S}=$ Volume of the water sample taken.

Mc Hugh (2003) observed that microalgae Scenedesmus and Chlorella, and cyanobacteria Phormidium and Oscillatoria are the most frequently used genera in wastewater treatment systems mediated by microalgae and/or cyanobacteria. The use of these microorganisms lead to a progressive reduction of chemical oxygen demand (COD) and biological oxygen demand (BOD), to values below the disposal limits. Kotteswari et al.2012 worked on the dairy effluent collected from Madavaram dairy plant, Chennai, India where he found Nostocsp. decreased the total reduced solids to $53.93 \%$, total dissolved solids to $20.21 \%$, alkalinity to $18.13 \%$ and phosphate content to $21.08 \%$ in the effluent. Also, BOD and COD levels were reduced to 40.25 and $44.44 \%$, respectively. Microalgae have also been successfully employed in the reduction of heavy metal content in industrial wastewaters, both in batch or in continuous systems.

\section{Adsorption isotherm method}

Several algal strains show high affinity toward adsorption and absorption towards heavy metals at specific $\mathrm{pH}$ and temperature and these metals are used by them as a part of their nutrition and convert them in to non-toxic substance (Oswald, 2012). Aksuet.al. 1991was investigated adsorption of dissolved metals from industrial wastewater by using green alga Chloella vulgaris to remove lead ions (II). Single batch reactor was used to study adsoption of metals and residual or adsorbed metal concentration was calculated with Freundlich adsorption isotherm method. These finding suggested that it is a good alternative technique for treatment of industrial waste water containing heavy metals (Aksu et. al. 1992).The process of removal of metal contaminants from those sites having high concentration of heavy metals can be achieved using nonviable biomass as biosorbents (Kotrba \& Ruml, 2000; Singh et al., 2007; Loutseti et al., 2009). Biomass obtained from different algal species differ largely in their binding capacity for various heavy metals (Chong et al., 2000; Donmez et al., 1999; Klimmek et al., 2001; Wilke et al., 2006; Micheletti et al., 2008; Mishra et al., 2011). The metal-binding capacity of biosorbents depend on the cell wall composition of the organism and on the chemical

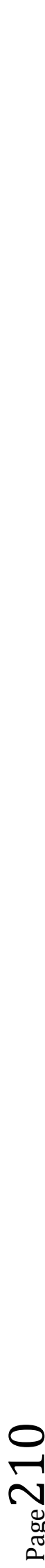


composition of the metal ion solution to be treated (Drora k. 2013). Therefore, in order to choose the most adequate biosorbent for metal decontamination of a specific site, it is essential to know which metals are present there and the concentration of each. Selection of the appropriate biomass is actually dictated by the metals to be removed, and the correct choice is essential for achieving efficient bioremediation.

\section{Centrifugation method}

This method involves the use of algal biomass instead of water sample which undergoes dewatering followed by centrifugation. Udom et.al. (2013) described a method for harvesting microalgae that have grown in wastewater. Algae were grown in semi-continuous culture in pilotscale photo bioreactors under natural light with anaerobic digester centrate as the feed source. Algae suspensions were collected and the optimal coagulant dosages for metal salts (alum, ferric chloride), cationic polymer (Zetag 8819), anionic polymer (E-38) and natural coagulants (Moringa Oleifera and Opuntia, ficus indica, cactus) were determined using jar tests. The relative dewater ability of the algae cake was estimated by centrifugation. Several coagulants, including ferric chloride, alum and cationic polymers, could achieve $>91 \%$ algae recovery in jar tests without $\mathrm{pH}$ adjustment. Ferric chloride had the highest cost but the lowest environmental impacts, while the cationic polymer had the lowest cost but the highest environmental impacts. Belt presses are recommended for dewatering because they can meet the solids content requirements for downstream processing with lower energy consumption and GHG emissions than other dewatering technologies. There is no suggestion for reducing the cost level. Effect of addition of coagulant on algae is also lacking.

\section{Gas chromatography and mass spectrometry (GC-MS) method}

The use of algae is having some advantage as some compounds can be produced which are potentially useful for the environment. Thus, there is mutual benefit while treating the waste water with algae (H. Mahdavi et.al. 2015). Mahapatra et.al. (2014) collected wastewater from the inflow channels (Bellandur Lake, Koramangala region, South of Bangalore, India) and allowed to settle for 2 days and is used to grow algae of nearly directly fed with 20 species. The nutrient removal efficiencies and lipid content were studied using Gas chromatography and mass spectrometry (GC-MS).The nutrient removal efficiencies are $86 \%, 90 \%, 89 \%, 70 \%$ and $76 \%$ for Total Organic Carbon(TOC), Total Nitrogen (TN), Ammonium Nitrogen $\left(\mathrm{NH}_{4}-\mathrm{N}\right), \quad$ Total Phosphate(TP)and Ortho Phosphate (OP) respectively, and lipid content varied from $18 \%$ to $28.5 \%$ of dry algal biomass. Biomass productivity of $122 \mathrm{mg} / 1 / \mathrm{d}$ (surface productivity $24.4 \mathrm{~g} / \mathrm{m} 2 / \mathrm{d}$ ) and lipid productivity of $32 \mathrm{mg} / \mathrm{l} / \mathrm{d}$ were recorded. The decomposition of algal biomass and reactor residues with an exothermic heat of 123.4 $\mathrm{J} / \mathrm{g}$ provides the scope for further energy derivation. Development of lipid production from single species study is still lacking.

\section{Colorimetric method}

In colorimetric method assessment of toxic metal from industrial effluents was carried out for example a toxic metal Chromium which is present in the effluents of dye, tanning, paper-pulp, printing and the electroplating industries is carcinogenic and mutagenic. Yewalkaret al. (2007) concluded that the disappearance of $\mathrm{Cr}(\mathrm{VI})$ from the medium was the result of reduction by live algal cells of Chlorella sp., since the cell supernatant did not show this activity. This reduction was not merely due to absorption of chromium in the cells as studies showed the cells retained only $10-21 \%$ of total $\mathrm{Cr}(\mathrm{VI})$. Colorimetric assay showed 50\% reduction in the $\mathrm{Cr}(\mathrm{VI})$ concentration under similar conditions 
which may be due to the conversion of $\mathrm{Cr}(\mathrm{VI})$ to Cr(III) by Chlorellasp. Nitellasp. can also be effectively used tore mediate $\mathrm{Cr}(\mathrm{VI})$ contaminated water either passively or actively in wetland systems, depending upon the concentration of $\mathrm{Cr}(\mathrm{VI})$.

\section{UV Spectrophotometry method}

UV spectrophotometry method was described by Nayana et.al. (2016) where he shows that two algal species Spirogyra $s p$. and Oscillatoria $s p$. used for bioremediation of textile industrial effluents having blue and red dye. In this experiment after 14 days of incubation of waste water sample from textile industry the UV and visible spectra of the samples were measured byUV-1800 Series. Quartz cells (1 cm square) having $1.0 \mathrm{~cm}$ path length was used for the determination. Hydrogen discharge tungsten filament lamp was used as a source of light and maximum absorbance was recorded. UV Spectroscopy of untreated blue dye effluent showed peaks at 737, 223, 490 and $220.5 \mathrm{~nm}$. After treatment of blue dye with Spirogyra $s p$. showed peaks at 736, 615, 720 and $492 \mathrm{~nm}$. Whereas treatment of blue dye with Oscillatoria sp. showed peaks at 739, 615, 222, 726, 488 and $219 \mathrm{~nm}$. In case of untreated red dye effluent showed peaks at 285 and $265 \mathrm{~nm}$. After treatment of red dye with Spirogyra sp. showed peaks at 348,282, 274, 234, 338, 280, 260 and $217 \mathrm{~nm}$ whereas treatment of red dye with Oscillatoria sp. showed peaks at 348, 282, 274, 234, 337, 280, 260 and $217 \mathrm{~nm}$ with different absorption value. These obtained results of UVVisible analysis proving that both dyes changed to other compounds. Kumar et.al. observed bioremedial potential of marina micro algae Chlorella marina on industrial effluents where he found C. marina decreases 64\% ammonia, 51\% phosphorous, $88 \%$ of nitrite and $75 \%$ of nitrate. Das et.al. observed 100\% reduction of nitrate and chromium in period of 21 days by C. Vulgaris.

\section{CONCLUSION:}

Algae has ability to utilize certain pollutant such as heavy metals or as a part of its nutrition and hence useful in reducing the toxic level of these pollutants fromsites which become polluted due to effluents from various industries. Use of algae for bioremediation of pollutants is a cost-effective technique and done either with In-situ or Ex-situ approach. To assess the potential of bioremediation by using certain microalgae qualitatively as well as quantitatively various methods are used depending upon the site of contamination and the type of contaminants itself. Out of these methods most common methods are physicochemical methods particularly used to assess the quality of contaminated water. Adsorption isotherm method is used for quantitative analysis of heavy metal pollutants. Centrifugation method uses algal biomass instead of water for assessment of contaminants however this method is not cost effective and requires some coagulants whose effect on algae is also lacking. Gas chromatography and mass spectrometry (GC-MS) method is useful for quantitative assessment of variety of pollutants including organic components as well as heavy metals. Colorimetric method and UV spectrophotometry method is useful for detection of contaminants which are in soluble form such as dye agents, dissolve salts, etc. although it is not cost effective but provides the more precise results.

\section{REFERENCES:}

Ahluwalia S.S. and Goyal D (2007). "Microbial and plant derived biomass for removal of heavy metals from waste water", Bioresouce Technology, Vol. 98, pp. 2243-2257.

Aksu Z., Kutsal T. (1991). A bioseparation process for removing lead (II) ions from waste 
water by using C. vulgaris. J. Chem. Technol. Biotechnol.,52:109-118.

Aksu Z., Sag Y., Kutsal T. (1992). The biossorpnon of copperod byC. vulgaris and $Z$. ramigera. Environ. Technol., 13:579-586

Ansari M.I., Malik A. (2007). Biosorption of nickel and cadmium by metal resistant bacterial isolates from agricultural soil irrigated with industrial wastewater, Bioresour. Technol. 98: 3149-3153.

Ambast, R.S.(1990).Environment and Pollution (An Ecological Approach). Ist (Eds.), Students Friends Publications, Lanka Varanasi, India.

Amin, H., Amer, A., El Fecky, A., Ibrahim, I. (2008). Treatment of textile waste water using H2O2/UV system. Physicochem. Probl. Miner. Process. 42: 17-28.

APHA. Standard methods for the examination of water and wastewater (1998). 18th Edition. American Public health Association, Washington, DC pp. 45-60.

APHA, AWWA, WEF, (2005). Standard Methods for the Examination of Water and Wastewater, 20th ed. APHA, Washington, DC, USA

Brahmbhatt N. H., Jasrai R. T. (2016). The Role of Algae in Bioremediation of Textile Effluent, International Journal of Engineering Research and General Science Volume 4, Issue 1, January-February, ISSN 2091-2730.

Bundschuh, J., Litter, M.I., Parvez, F., RománRoss, G., Nicolli, H.B., Jean, J., Liu, C., López, D., Armienta, M.A., Guilherme, L.R.G., Cuevas, A.G., Cornejo, L.,
Cumbal, L., Toujaguez, R. (2012). One Century of Arsenic Exposure in Latin America: A Review of History and Occurrence from 14 Countries, Sci. of theTotalEnviron., 429: 2-35.

BunluesinS., Kruatrachue M., Pokethitiyook P., Upatham S., Lanza G.R. (2007) . Batch and continuous packed column studies of cadmium biosorption by Hydrillaverticillata biomass, J. Biosci. Bioeng. 103: 509-513.

Cai S, Park YS, Li Y. (2013). Nutrient recovery from wastewater streams by microalgae: Status and prospects. Renewable and Sustainable Energy Reviews.19:360-369.

Chekroun K. B. , Baghour M. (2013). "The role of algae in phytoremediation of heavy metals: A review", Journal of Materials and Environmental Science, Vol. 4(6), pp. 873-880.

Chong, A.M.Y., Wong, Y.S. \& Tam, N.F.Y. (2000). Performance of different microalgal species in removing nickel and zinc from industrial wastewater. Chemosphere 41: $251-257$.

Das C., Naseera K., Ram A., Meena R.M., Ramaiah N.(2017). Bioremediation of tannery wastewater by a salt-tolerant strain of Chlorella vulgaris. J. Applied Phycol., 29:235-243.

Department of the Environment, Australia (DEA), (2001). Land Theme Report,

Donmez, G.C., Akzu, Z., Ozturk, A. \&Kutsal, T. (1999). A comparative study on heavy metal biosorption characteristics of some algae. Process Biochem. 34: 885-892. 
DroraK. (2013). Absorption and Adsorption of Heavy Metals by Microalgae.

Dursun A.Y. (2003). The effect of $\mathrm{pH}$ on the equilibrium of heavy metalbiosorption by Aspergillusniger, Fresenius Environ. Bull. 12 (11) 1315-1322.

Dwivedi S. (2012). Bioremediation of heavy metal by algae: Current and future perspective. J. Adv. Lab. Res. Biol.,3:195-199.

Folch A., Vilaplana M., Amado L., Vicent R., Caminal G. (2013) Fungal permeable reactive barrier to remediate groundwater in an artificial aquifer. $J$ Hazard Mater. ;62:554-560.

Frascari D, Zanaroli G, Danko A.S. (2014). In situ aerobic co-metabolism of chlorinated solvents: a review. J Hazard Mater. 2015;283:382-399.

Ghimire K.N., Katsutoshi I., Keisuke O., Hayashida T. (2007). Adsorptive separation of metallic pollutants onto waste seaweeds, Porphyrayezoensis and Ulva Japonica, Sep. Sci. Technol. 42: 2003-2018.

Harneet K., Rajor A. and Kaleka A. S. (2019). Role of Phycoremediation to Remove Heavy Metals from Sewage Water: Review Article, Journal of Environmental Science and Technology. ISSN 1994-7887.

Howe G. and S. Merchant (1992). Heavy metalactivated synthesis of peptides in Chlamydomonasreinhardtii. Plant Physiol.,98: 127-136

Johnson M. P. (2016), "Photosynthesis," Essays in Biochemestry, vol. 60, no. 3, pp. 255273.
Kim S, Krajmalnik-Brown R, Kim J-O, Chung J. (2014). Remediation of petroleum hydrocarbon-contaminated sites by DNA diagnosis-based bioslurping technology. Sci Total Environ. 497:250259.

Klimmek, S., Stan, H.J., Wilke, A., Bunke, G. \& Buchholz, R. (2001). Comparative analysis of the biosorption of cadmium, lead, nickel, and zinc by algae. Environ. Sci. Technol. 35: 4283-4288.

Kotteswari M, Murugesan S, Ranjith Kumar R (2012) Phycoremediation of dairy effluent by using the microalgae Nostoc sp. Int JEnviron Res Dev 2:35-43

Kotrba, P. Ruml, T. (2000). Bioremediation of heavy metal pollution exploiting constituents metabolites and metabolic pathways of livings. A review. Collect. Czech Chem. Commun. 65: 1205-1247.

Kumar D., Santhanam S.P., Jayalakshmi T., Nandakumar R. Ananth, Dev A.S. Praksath B.B. (2015). Excessive nutrients and heavy metals removal from diverse wastewaters using marine microalga Chlorella marina (Butcher). Indian $\mathrm{J}$. Mar. Sci., 44:97-103.

Loutseti, S., Danielidis D.B., Economou-Amilli, A., Katsaros, Ch., Santas, R. \&Santas, Ph. (2009). The application of a microalgal/bacterial biofilter for the detoxification of copper and cadmium metal wastes. Bioresour. Technol. 100: 2099-2105.

Luo, Y., Wu, L., Liu, L., Han, C., Li, Z. (2009) Heavy Metal Contamination and Remediation in Asian Agricultural Land, National Institute of Agro-Environmental 
Sciences, MARCO Symposium, Japan, October 5-7.

MahapatraD., ChanakyaH., RamachandraT. (2014). Bioremediation and lipid synthesis through mixotrophic algal consortia in municipal wastewater, Bioresour. Technol. 168: 142-150.

MahdaviH., PrasadV., LiuY., UlrichA.C. (2015). In situ biodegradation of naphthenic acids in oil sands tailings pond water using indigenous algae-bacteria consortium, Bioresour. Technol. 187:97-105.

Mallick N. (2003). Biotechnological potential of Chlorella vulgaris for accumulation of $\mathrm{Cu}$ and $\mathrm{Ni}$ from single and binary metal solutions, World J. Microbiol. Biotechnol. 19: 695-701.

Mc Hugh, D.J. (2003). A guide to the seaweed industry. FAO Fisheries Technical Papers 441: pp. 101-115.

Mishra, A., Kavita, K. \& Jha, B. (2011) Characterization of extracellular polymeric substances produced by microalgae Dunaliellasalina. Carbohydr. Polym. 83: 852- 857

Mitra, N., Rezvan, Z., Seyed Ahmad, M., Gharaie, M., Hosein, M. (2012). International Journal of Ecosystem. 2: 32.

Murali, O. and Mehar S.K. (2014). Bioremediation of heavy metals using Spirulina. Int J. Geol. Earth Environ. Sci., 4:244-249.

Nayana H. B. and Jasrai R. T.(2016). The Role of Algae in Bioremediation of Textile Effluent. International Journal of Engineering Research and General Science Volume 4, Issue 1, January-February, ISSN 2091-2730.
Oswald W.J. (2012). My sixty years in applied algology. J. Applied Phycol., 15: 99-106.

Philp J.C, Atlas R.M. (2005). Bioremediation of contaminated soils and aquifers. Bioremediation: applied microbial solutions for real-world environmental cleanup. Washington: American Society for Microbiology (ASM) Press;. pp. 139236.

Rawat I, Kumar RR, Mutanda T, Bux F (2011). Dual role of microalgae: phycoremediation of domestic wastewater and biomass production for sustainable biofuels production. Appl Energy 88:3411-3424.

Roy M, Giri A. K, Dutta S., Mukherjee P. (2014). Integrated phytobial remediation for sustainable management of arsenic in soil and water. Environ Int. 75:180-198.

Saikumar Chalivendra (2014). Bioremediation of wastewater using microalgae, Ph.D. Thesis, The School of Engineering of the UNIVERSITY OF DAYTON.

Sasikumar, C.Sheela ,Taniya Papinazath (2003). "Environmental Management: Bioremediation of Polluted Environment, Third International Conference on Environment and Health, Chennai, India, Chennai. Pages 465 - 469.

Shift Soil Remediation (SSR), Soil Contamination in West Africa, 2010.

Singh, A., Mehta, S.K. \& Gaur, J.P. (2007).Removal of heavy metals from aqueous solution by common freshwater filamentous algae. World J. Microbiol . Biotechnol. 23: 1115- 1120. 
Standard Methods for the Examination of Water and Wastewater, 17th ed., American Public Health Association: Washington, D.C. 1989.

Udom I., ZaribafH.B., HalfhideT., GillieB., DalrympleO., ZhangQ., et al. (2013). Harvesting microalgae grown on wastewater, Bioresour. Technol. 139:101106.

Valderrama, L. T., C. M. Del Campo, C. M. Rodriguez, L. E. De Bashan and Y. Bashan. (2002). Treatment of recalcitrant wastewater from ethanol and citric acid production using the microalga Chlorella vulgaris and the macrophyte Lemnaminuscula. Water Research, 36 (17): 4185-4192.

Wang J. Chen C. (2009). Biosorbents for heavy metals removal and their future, Biotechnol.Adv.27:195-199.
Wilke, A., Buchholz, R. \&Bunke, G. (2006).Selective biosorption of heavy metals by algae. Environ. Biotechnol. 2(2): 47-56.

YatiPrabha (2012). Potential of Algae in Bioremediation of Waste Water Ph.D. Thesis Dayalbagh Educational Institute (Deemed University)Dayalbagh, Agra.

Yewalkar S.N., Dhumal K.N., Sainis J.K. (2007). Chromium (VI) reducing Chlorella spp. isolated from disposal sites of paper pulp and electroplating industry. J Appl Phycol 19:459-465.

ZiagovaM., Dimitriadis G., Aslanidou D., PapaioannouX.,Litopoulou-TzannetakiE., Liakopoulou-KyriakidesM., (2007) Comparative study of $\mathrm{Cd}$ (II) and $\mathrm{Cr}(\mathrm{VI})$ biosorption on Staphylococcus xylosus and Pseudomonas sp, Bioresour. Technol. 98: 2859-2865. 
Table: various assessment methods used in determination of bioremediation potential of microalgae

\begin{tabular}{|c|c|c|c|}
\hline Methods & $\begin{array}{c}\text { Micro Algal strain } \\
\text { used }\end{array}$ & Results obtained & Reference \\
\hline $\begin{array}{l}\text { Physico-chemical } \\
\text { assessment methods }\end{array}$ & $\begin{array}{l}\text { Scenedesmus, } \\
\text { Chlorella, } \\
\text { OscillatoriaNostoc }\end{array}$ & $\begin{array}{l}\text { In wastewater treatment reduction of } \\
\text { chemical oxygen demand (COD) and } \\
\text { biological oxygen demand (BOD), to } \\
\text { values below the disposal limits. } \\
\text { In dairy effluents decreased the total } \\
\text { reduced solids to } 53.93 \% \text {, total } \\
\text { dissolved solids to } 20.21 \% \text {, alkalinity } \\
\text { to } 18.13 \% \text { and phosphate content to } \\
21.08 \% \text { in the effluent. Also, BOD } \\
\text { and COD levels were reduced to } \\
40.25 \text { and } 44.44 \% \text {, respectively. }\end{array}$ & $\begin{array}{l}\text { Mc Hugh (2003), } \\
\text { Kotteswari et. al.2012 }\end{array}$ \\
\hline $\begin{array}{l}\text { Adsorption isotherm } \\
\text { method }\end{array}$ & Chloella vulgaris & $\begin{array}{l}\text { Adsorption of dissolved metals from } \\
\text { industrial wastewater to remove lead } \\
\text { ions (II). } \\
\text { High concentration of heavy metals } \\
\text { can be removed using nonviable } \\
\text { biomass as biosorbents. }\end{array}$ & $\begin{array}{l}\text { Aksu et. al. } 1991 \\
\text { Kotrba\&Ruml, } 2000 \text {; } \\
\text { Singh et al., 2007; } \\
\text { Loutseti et al., } 2009\end{array}$ \\
\hline $\begin{array}{l}\text { Centrifugation } \\
\text { method }\end{array}$ & $\begin{array}{l}\text { Chlorella, } \\
\text { Oscillatoria }\end{array}$ & $\begin{array}{l}\text { use of algal biomass instead of water } \\
\text { sample } \\
\text { Undergoes dewatering followed by } \\
\text { centrifugation; requires coagulants } \\
\text { such as ferric chloride, alum and } \\
\text { cationic polymers, which achieve } \\
>91 \% \text { algae recovery in jar tests } \\
\text { without pH adjustment. }\end{array}$ & Udomet.al.(2013) \\
\hline $\begin{array}{l}\text { Gas } \\
\text { chromatography and } \\
\text { mass spectrometry } \\
\text { (GC-MS) method }\end{array}$ & $\begin{array}{l}\text { Scenedesmusquadri } \\
\text { cauda, } \\
\text { S. obliques, } \\
\text { C. vulgaris, } \\
\text { C.pyrenoidosa, } \\
\text { Chlorococcumhumic } \\
\text { ola, Chroococcussp }\end{array}$ & 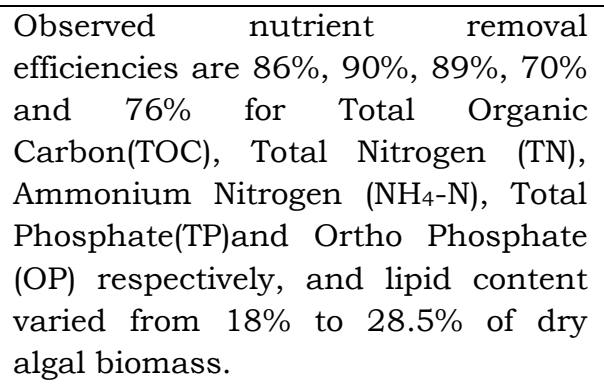 & Mahapatraet.al.(2014) \\
\hline Colorimetric method & $\begin{array}{l}\text { Chlorellasp., Nitellas } \\
\mathrm{p}\end{array}$ & $\begin{array}{l}\text { Colorimetric assay showed } 50 \% \\
\text { reduction in the } \mathrm{Cr}(\mathrm{VI}) \text { concentration } \\
\text { under similar conditions which may } \\
\text { be due to the conversion of } \mathrm{Cr}(\mathrm{VI}) \text { to } \\
\mathrm{Cr}(\mathrm{III})\end{array}$ & Yewal karet al. (2007) \\
\hline $\begin{array}{l}\text { UV } \\
\text { Spectrophotometry } \\
\text { method }\end{array}$ & $\begin{array}{l}\text { Spirogyra sp., } \\
\text { Oscillatoria sp., } \\
\text { Chlorella marina }\end{array}$ & $\begin{array}{l}\text { Bioremediation of textile industrial } \\
\text { effluents having blue and red dye. } \\
\text { Decreases } 64 \% \text { ammonia, } 51 \% \\
\text { phosphorous, } 88 \% \text { of nitrite and } 75 \% \\
\text { of nitrate from industrial effluents. }\end{array}$ & $\begin{array}{l}\text { Nayana et.al. (2016) } \\
\text { Kumar et.al (2015) } \\
\text { Das et.al. (2017) }\end{array}$ \\
\hline
\end{tabular}

